\title{
DOCUMENTS
}

\section{Paul Meier}

\section{AN UNPUBLISHED LECTURE OF WILLIAM MORRIS}

In 1969, ten unpublished lectures of William Morris, which had been for years lying among the British Museum Additional Manuscripts, were at last edited by the American Professor Eugene D. LeMire. ${ }^{1}$ This valuable collection is supplemented by two appendices of outstanding scholarship, which make of this book an indispensable tool. One is a "Calendar of William Morris's platform career", and the other a "Bibliographical Checklist of Morris's speeches and lectures". If we refer to the entry of March 1st, 1889, we may read: "'How Shall We Live Then?' delivered at a meeting sponsored by the Fabian Society, in Bloomsbury Hall, London. Mr. William Clarke was chairman. Source: To-Day, XI (April, 1889), 120-21." The lecture was repeated two days later, on March 3rd, at Kelmscott House, for the Hammersmith Branch of the Socialist League. Morris judged it important enough to deliver it again three times in the course of the following year: on January 22nd, for the North London Branch of the Socialist League, at 6 Windmill Street, Tottenham Court Road; on February 22nd, for the Leicester Radical Club, at the Club rooms, Vine Street, Leicester; and on March 2nd, for the North Kensington Branch of the Socialist League, at the Clarendon Coffee Tavern. When we now refer to Professor LeMire's bibliographical check list, we read that "no text remains". ${ }^{2}$ It was our luck to discover that the original manuscript still existed and was preserved in the archives of the International Institute of Social History, Amsterdam.

How it eventually came there is still a mystery. The main difficulty in our endeavour to solve it lies in the fact that much of the pre-war correspondence of the Institute has disappeared, and so have the packing lists which were made when part of the archives and collections was stored in Oxford during the hostilities. The only indication which might help further research is the likeness its beautiful binding

1 The Unpublished Lectures of William Morris, edited and compiled by Eugene D. LeMire (Detroit, 1969).

Ibid., pp. 278, 282, 314 . 
bears to those of the Kashnor Collection, bought by the Institute in 1938 from the Kashnor brothers, of London, well-known dealers in second-hand rare books. This stupendous collection essentially consists of books and pamphlets, some of them unique copies, published between 1572 and 1866. Unfortunately, no catalogue of this sale remains, and we must be content with the pages of the Institute's annual report for 1938 dealing with this acquisition, and with an article on the same subject published by the Bulletin of the Institute (Vol. II, 1938). Yet, in neither of those publications is any mention of Morris's manuscript to be found. This should not, however, be regarded as conclusive. They cannot be considered as being an exhaustive repertory of the Kashnor Collection, and the fact that it essentially consisted of printed matter may well explain that no special attention was given to the manuscript. The binding seems to be a safer piece of evidence. Anyhow, even if this hypothesis is one day confirmed, the mystery subsists as to how this unpublished lecture was not, like all the others, stored in the British Museum.

As stated before, this lecture was delivered on March 1st, 1889, at a meeting of the Fabian Society. The date and place are not immaterial. This was a year when William Morris was, in his political activity, urged by two apparently conflicting motives. Fundamentally a Marxist and a revolutionary, he was fighting uncompromisingly against reformist ideology, and the increasing impact of Fabianism was felt by him as a dangerous threat on the movement. In March, this feeling was yet no more than a strong misgiving. A few months later, after the tremendous success of Edward Bellamy's Looking Backward and the publication of the Fabian Essays, his reaction became unmitigated and violent. ${ }^{1}$ In the meanwhile, this misgiving was counteracted by another concern which was no less imperative, and that was the consciousness of how feeble the Socialist movement was and how harmful the internecine warfare within it might be. Bloody Sunday (Nov. 13th, 1887), with its brutal reminder of the power of the ruling class, had shattered many illusions Morris had hitherto nourished, and the necessity of union forced itself urgently upon his mind. In August 1889,

1 Cf. his review of Looking Backward, in: Commonweal, June 22nd, 1889, pp. 194-5, and of Fabian Essays, ibid., January 25th, 1890, p. 28. His growing concern is pointedly re-asserted in his last contribution to Commonweal: "The success of Mr. Bellamy's Utopian book, deadly dull as it is, is a straw to show which way the wind blows. The general attention paid to our clever friends, the Fabian lecturers and pamphleteers, is not altogether due to their literary ability; people have really got their heads turned more or less in their direction." ("Where are we now?", in: Commonweal, November 15th, 1890, p. 362) 
he was to express the feeling of such a necessity in terms strikingly reminiscent of those used in the recent lecture How shall we live then? In an article of Commonweal, we read indeed: "I think the fewer party-names and distinctions we can have the better, leaving plenty of scope for the inevitable differences between persons of different temperaments, so that various opinions may not make serious quarrels." 1

It is in this divided state of mind that he addresses his Fabian audience in March. He is well aware that they do not share his views about the road to Socialism. So he chooses a devious approach. Instead of speaking of the means, he will talk about the end and develop his own vision of the society of the future when it has reached the stage of communism, a subject which, he says, cannot and should not be a matter of controversy between socialists. He has, by so doing, another avowed aim, i.e. to enthuse Socialists with the concrete perspective of the goal to be reached, so that they may find pleasure and inspiration in the dull chores of everyday "practical" militancy. This was a constant preoccupation with him, which he had often voiced before, and with special emphasis in a lecture delivered in 1886, The End and the Means. ${ }^{2}$

There is yet a further and deeper intention to be perceived, which appears in all the writings of William Morris and has been overlooked by most critics and historians. He is indeed the only Socialist of his period in England to have been the explicit exponent of the Marxist theory of the two successive stages of Socialism and Communism, the former being only a transition. This theory had been formulated for the first time by Karl Marx in his Critique of the Gotha Programme, which, for opportunist reasons, was not published by the German social-democratic leaders till 1891. Its manuscript was in the hands of Friedrich Engels since Marx's death in 1883. What is extraordinary and should have drawn more attention is that the theory of the two stages is developed by Morris as early as 1885, in the Notes appended to the October edition of the Manifesto of the Socialist League. ${ }^{3}$ The style of these Notes, signed by both Morris and Belfort Bax, is still confused, but it is with perfect clarity that, from then on, the theory of the two stages appears in Morris's lectures, articles and correspondence. My own research has enabled me to prove that the striking similitude between many writings of Morris and many Marxist texts (some of which still unpublished then), on this special point and on many others,

1 "Communism and Anarchism", in: Commonweal, August 17th, 1889, p. 261. 2 The text of this lecture is to be found in May Morris, William Morris, Artist, Writer, Socialist, II, p. 420.

3 The Manifesto is reproduced by E. P. Thompson, William Morris: Romantic to Revolutionary; the Note C, alluded to here, is on pp. 854-5. 
could only be the result of close and frequent contacts, from 1884 till 1886, between Morris and Engels. ${ }^{1}$

The theory of the two stages is a fundamental element of Morris's Utopian thought. When he addresses his Fabian audience, on March 1 st, 1889 , he is concerned with fostering a climate of fellowship between Socialists of different sects, and does not wage a frontal attack against reformism. But there is a point on which he is clear. The society of the future which he describes is not the society of State Socialism. He will not have it that this stage should be regarded as final. The Fabian ideal is, in his eyes, limited and narrow and excludes the prospect of "complete" Socialism, or Communism, which ought to be the end in view. He refuses to be content with "the instrument of the transition, which is what some understand by the word Socialism". This brief passage provides the political clue of the lecture How shall we live then?

This lecture is also intended to teach the audience another lesson, that of the necessity of theoretical education, and this is done in such terms as make How shall we live then? a document of outstanding interest for the understanding of Morris's ideological evolution. He rejects the Fabian middle-class intellectual notion that one becomes a "genuine" Socialist just through abstract speculation. There must be at the outset, he says, a reaction of the whole being against the injustice of the present system, a reaction derived from personal experience. He gives his own case as an example and explains how he was thwarted in all his artistic work by the general degradation brought about by the conditions of life in capitalist society. He was helped in reaching this degree of consciousness by the reading of Ruskin's books. And here, by the way, he aims a decisive blow at the long-standing legend which represents him as a mere faithful disciple of Ruskin. Morris does not deny his influence, but, he points out, Ruskin influenced him "probably more than he intended", so that he became ready to join a "party with distinct aims for a revolution in society". And then began for him the necessity of acquiring a real theoretical education, of reading books and doing work "which I thought myself quite unfit for", - which clearly means that he eventually found that he was not so "unfit" for that sort of work as he had thought.

The reader will notice that, in the text of his lecture, Morris does not say what books he then read. A curious fact should be mentioned here. The only knowledge we had hitherto of the contents of this lecture was through the account given of it by an anonymous reporter

1 Cf. my article, "Friedrich Engels et William Morris", in: La Pensée, No 156, April 1971, pp. 68-80. 
in the Fabian magazine To-Day, in April 1889. This account is rather faithful on the whole, but, at this point, it runs thus:

"He was a Socialist long before he knew that Socialism had its foundation in history, philosophy and economics. As to the last, 'you may imagine', said Mr. Morris, 'what my sensations were on taking my first plunge into Karl Marx's Capital', and the audience, with lively recollections of mathematical formulae, laughed and cheered sympathetically."1

The sentence quoted is not indeed to be found in the text. The lecture, besides, is carefully written from beginning to end, and its very length hardly leaves room for any ex tempore additions. One may even feel that Morris who, on other occasions, does not hesitate to mention Marx and recognise his debt to him, is careful not to make any allusion which might have antagonised his Fabian audience. If he actually pronounced the words quoted by the reporter (which is yet to be proved), we may notice how venomous the comment is. If he did not pronounce them, it would show that the audience had perfectly understood what he ineant.

The preamble to this lecture is exceptionally long, and it deserved to be commented on at some length so that Morris's intentions, cautiously expressed as they are, might be made quite clear. By itself, this preamble is a new and important addition to the corpus of his ideological writings.

The scholar who has made a special study of William Morris may not feel he discovers something very new when the author comes to his point and answers his own question: How shall re live then? It is a fact that most of the ideas expressed here about what the communist society will look like are scattered throughout Morris's writings of the 80 's and 90's. To some extent, it is reminiscent of the lecture he had given one year before about The Society of the Future, though the tone is more familiar here, more personal and concrete. A few points, however, are stressed in How shall we live then? with greater emphasis than anywhere else, such as education and federalisation. As regards the latter theme, we may even note that Morris is particularly explicit, and it is only in 1893, when he writes (jointly with Bax) his theoretical book Socialism, its growth and outcome, that he will resume the same ideas as completely. This does not seem to have been accidental. $\mathrm{He}$ was well aware of the Fabian leanings towards "municipal Socialism", and he might hope that his own communal system would rouse some interest among his audience.

1 "Fabiana", in: To-Day, XI, April 1889, p. 120. 
Morris is no less explicit on another important matter, that of the machines. Of course, a specialised student of Morris will not find here any statement that swerves from his usual stand on this question. It may yet be a surprise for the average reader, less conversant with Morris's ideology, to read that, in spite of a long-lived legend, the author of News from nowhere was by no means an enemy to the use of machines, an "intellectual Luddite" or a machine-breaker, as some eminent critics have sometimes described him. ${ }^{1} \mathrm{He}$ will find, on the contrary, that Morris demanded the mechanisation of all unpleasant tasks, whether toilsome or light, that of the office-clerk as well as that of the coal-miner. And even the specialists of Morris will be struck by the phrasing used here, when he wants the machines of the future to be "as nearly automatic as possible".

\section{HOW SHALL WE LIVE THEN?}

What I have to say to you relates to matters that may be discussed amongst Socialists, mingled or not with their declared opponents, but can not be altogether a matter of controversy amongst Socialists. I want to give you my personal view of the Promised Land of Socialism, with the hope of eliciting an account of the views of several of this audience; and I do not think the hour and a half so employed ought to be waste time if we tell each other honestly and as clearly as we can what our ideals are, if we have any, or confess to our having none if that is the case. We are engaged in a common adventure for the present, the abolition of the individual ownership or monopoly of the means of production; the attainment of that immediate end will bring about such a prodigious and overwhelming change in society, that those of us with a grain of imagination in them cannot help speculating as to how we shall live then: $:^{2}$ and the expression of the results of our speculations, of our hopes and fears will certainly give our friends and associates some insight into our characters, and temperaments, will make us know each other better; and that in turn will save much friction and loss of time, will in short make us better

1 Cf., for instance, Nikolaus Pevsner, Pioneers of modern design (Penguin Books), p. 25; or Robert Furneaux Jordan, Victorian Architecture (Penguin Books), p. 184.

2 Cf.: "such a stupendous change in the machinery of life as the abolition of capital and wages must bring about a corresponding change in ethics and habits of life" ("On some practical 'Socialists"”, in: Commonweal, Feb. 18th, 1888, p. 52). 
friends; to come sometimes from out of the hedge of party formulas and show each other our real desires and hopes ought to be something of a safeguard against the danger of pedantry which besets the intellectual side of the Socialist movement and the danger of machine politics which besets its practical and work-a-day side.

It is true that as some of you may have anticipated my paper must necessarily under these conditions take a personal character and be somewhat egoistical. I do not offer an apology for that but I may offer an explanation. I have some 55 years experience, I won't say of the world, but of myself ; $;$ the result of which is that I am almost prepared to deny that there is such a thing as an individual human being: I have found out that my valuable skin covers say about a dozen persons, ${ }^{2}$ who in spite of their long alliance do occasionally astonish each other very much by their strange and unaccountable vagaries; by their profound wisdom, their extreme folly, their height of elevation, and their depth of baseness. So that though it may be possible that the complex animal who has now the pleasure of addressing you has not his double in the world, (though I decline to admit that also) it is impossible but that the men inside my skin who go to make up that complexity are but types of many others in the world, and probably even some of those are in this room at present. So that when I tell you of my so-called personal desires for and hopes of the future the voice is mine, but the desires and hopes are not only mine, but are those of, I really think, many others, and you as practical men, as I hope you are, cannot afford to disregard them.

Now I will ask what draws men into the Socialist ranks at this stage of the movement? I mean of course what makes them genuine socialists. I do not think it can be any hope of personal advancement; such hopes would be much too wild to be entertained by anyone who had wits enough to feed himself with a fork; for the most sanguine of us know that there will be such heaps of trouble of one kind or another before the first serious blow has got any reason at all out of the monopolists, that mere trouble is pretty certain to be part of our reward for daring to hope that society can be improved. Is it intellectual conviction deduced from the study of philosophy or from that of politics or economics in the abstract? I suppose that there are many people who think that this has been the means of their conversion; but

$1 \mathrm{~W}$. Morris was born at Walthamstow in 1834 .

${ }^{2}$ Cf.: "he once wondered [...] which of six distinct personalities he himself really was" (Walter Crane, "In Memory of William Morris", in: Freedom, Nov. 1896, p. 109); "Perhaps, as he himself seems to have said, he was several personalities rolled into one" (Edward Carpenter, "William Morris", in: Freedom, Dec. 1896, p. 118). 
on reflection they will surely find that this was only its second stage: the first stage must have been the observation that there is a great deal of suffering in the world that might be done away with. That is I think the first thing that draws a man toward the socialists, whether he feels the suffering in his own person, and becomes conscious of a wrong done to him by what we now call society; a wrong which is not accidental but can be fixed on a certain set of events; or whether he himself is unconsciously one of those who do the wrong, but has the ordinary good-natured wish which any one who is not a mere illconditioned blackgard ${ }^{a}$ will have, to see all men as happy as they can be.

Now in this respect the corporation which I call $I$ is not at all peculiar: from the earliest time that I can remember catching myself thinking (an operation which all healthy and happy young people avoid as much as possible) the thought was from time to time thrust upon me that the greater part of people were ill-fed, ill-clad ill-housed overworked, and as a consequence nasty and disagreable. ${ }^{b}$ These thoughts made me uncomfortable and discouraged ${ }^{1}$ and took the flavour out of my amusements and my work (there was not much distinction between the two ${ }^{2}$ ) so of course I thrust them aside as much as I could. Yet I was conscious that I was acting a shabby part in doing so, for I was not such a fool as not to see clearly that these degraded persons that came between me and my pleasure had not degraded themselves, and that consequently there was something or other which a strong and honest man could attack. In all this there was nothing peculiar: you would say that a natural sense of the injustice of our Society was growing up in me, as it has surely in many others of my class and condition. ${ }^{3}$ But in what followed I was perhaps peculiar. I was indifferent honest, I was by no means strong; for I must tell you that one of those persons inside my skin is the peaceablest, and another the laziest of all persons - in that again I am not peculiar. So

a Morris's spelling

b Morris's spelling

1 This is, indeed, a feeling which finds frequent expression in Morris's preSocialist period. He would, for instance, write to Mrs George Howard, in August 1874: "Do you know, when I see a poor devil drunk and brutal I always feel, quite apart from my aesthetical perceptions, a sort of shame, as if I myself had some hand in it." (The Letters of William Morris to his family and friends (London, 1950), p. 64)

2 Morris's son-in-law, H. Holliday Sparling, wrote that he "held that he was idling while doing that which would have exhausted any other man I have ever known" (The Kelmscott Press and William Morris, master-craftsman, p. 11).

${ }^{3}$ Even in his Socialist years, Morris was always ready to ackowledge his bourgeois origin: "we of the middle classes" is a recurrent phrase in his lectures. 
it is probable that that rising sense of injustice would have been damped down till I had grown old enough and tough enough to bear it easily: 1 but something happened to me that prevented that. Though my work was pretty much my amusement, yet it was serious enough to me: I daresay some of you would be astonished if you could understand the pleasure it has given me; but at last it gave me perhaps as keen a pain. It was a big job that I had taken in hand; no less than the regeneration of popular art as it used to be called. I was not fully conscious how big a job it was for a long time; though I was fully conscious of the complete degradation of the arts in general. Well the time came when I found out that those unpleasant thoughts about the greater part of the population were intimately connected with the very essence of my work, and at last that I had undertaken a job quite impossible under the present conditions of life. ${ }^{2}$ You may well think that I did not come to that conclusion all at once; in fact I tried to wriggle out of it for a long time till at last I was pinned, and there was the greater part gone of my pleasure in my work: which indeed was a serious matter for me, since $\mathbf{I}$ cared for it so much and so heartily. Well I cannot tell you whether it was about this time that I first heard of socialism as a definite movement, but I know that I had come to these conclusions a good deal through reading John Ruskin's works, and that $\mathrm{J}$ focussed so to say his views on the matter of my work and my rising sense of injustice, probably more than he intended, ${ }^{3}$ and that the result of all that was that I was quite ready for Socialism when I came across it in a definite form, as a political party with distinct aims

1 In a letter to Mrs Burne-Jones (June 1st, 1884), he had written: "if these were ordinary times of peace I might be content amidst my discontent, to settle down into an ascetic hermit of a hanger-on [...] but I don't see the peace or feel it" (The Letters, p. 200).

2 The impossibility for art to survive under capitalism is a constant theme throughout Morris's writings. In a letter to C. E. Maurice (July 1st, 1883), he had written: " $I[\ldots]$ assert the necessity of attacking systems grown corrupt and no longer leading anywhither: that to my mind is the case with the present system of capital and labour; as all my lectures assert, I have personally been gradually driven to the conclusion that art has been handcuffed by it, and will die out of civilisation if the system lasts." (The Letters, p. 175)

${ }^{3}$ All his life, Morris acknowledged his indebtedness to Ruskin and fervently remembered the decisive influence that such a book as The Stones of Venice especially had had on his own thinking. It would, however, be a gross error to believe that his admiration was unqualified. The discrepancy was indeed too great between Ruskin's religious and ethical spiritualism and Morris's overt materialism. As early as 1882 , Morris was writing that "one does not always agree with him" (May Morris, op. cit., II, p. 584). Earlier still, in 1860, he had grown impatient with the fifth volume of Modern Painters and declared that it was "mostly gammon" (J. W. Mackail, The Life of William Morris, I, p. 220). 
for a revolution in society. ${ }^{1}$ My position then which I am sure has been and is the position of many others, was profound discontent with the whole of modern life, a feeling of the deadly sickness of the world of civilization, which if I could have found no outlet for it would have resulted in sheer pessimism, as I think it often does. That outlet as you know I found, and I was hindered from coming to the conclusion that the art to which I had devoted myself was a mere idle folly, that I must go on with partly because I knew no other way of earning my livelihood, partly because I must have something more or less pleasant to do on some terms or other. My Socialism began where that of some others ended, with an intense desire for complete equality of condition for all men; for I saw and am still seeing that without that equality, whatever else the human race might gain it would at all events have to relinquish art and imaginative literature, and that to my temperament did and does imply the real death of mankind - the second death. Of course with the longing for equality went the perception of the necessity for the abolition of private property; so that I became a Communist before I knew anything about the history of Socialism or its immediate aims. And I had to set to work to read books decidedly distasteful to me, and to do work which I thought myself quite unfit for, and ${ }^{\text {a }}$ get myself into absurd messes and quarrel like a schoolboy with people I liked in order to become a practical Socialist - which rank I have no doubt some of you don't think I have gained yet. But all that did not matter because I had once again fitted a hope to my work and could take more than all the old pleasure in it; my bitterness dissappeared $^{\mathrm{b}}$ and - in short I was born again.

\section{a Manuscript reads in}

b Morris's spelling

Ruskin's incessant contradictions worried him; and he once said to G. Bernard Shaw "that he would write the most profound truths and forget them five minutes later" (May Morris, ibid., II, p. xxxii). He regretted the "damage Ruskin may have done to his influence by his strange bursts of fantastic perversity" (Commonweal, May 15th, 1886, p. 50). It would be a mistake as well to believe, as so many critics have done, that Morris's Socialism had its source in Ruskin. $\mathrm{He}$ is very clear on that matter: Ruskin, he wrote to Robert Thompson on July 24th, 1884, "is not a Socialist, that is not a practical one" (The Letters, p. 204). What he preserved of Ruskin's teaching was essentially an aesthetic lesson and the idea of "pleasure in work". All the rest subsided to the background after his first reading of Marx's Capital in 1883. Ruskin, he was to say in 1894, "before my days of practical Socialism, was my master" ("How I became a Socialist", in: Stories in Prose, Stories in Verse, Shorter Poems, Lectures and Essays, ed. by G. D. H. Cole, p. 657).

1 W. Morris joined Hyndman's Democratic Federation in January 1883 (the DF was to become the Social Democratic Federation in 1884), and seceded to found the Socialist League in December 1884. 
Now I repeat that I would not have said a word of all this, but that I know that what has happened to me has happened to other people though not quite in the same way. We, (I will say we now) are alive in the world and not in the least pessimists, but we are most sorely discontented with all things as they are, except the bare elements of life, and the hope for the future which we have somehow or other got into our heads.

We are alive and we can take the keenest pleasure in all those elements of life which the barbarian has in full measure but which civilization $^{1}$ has largely deprived us of: the sensuous pleasures of life is the technical word for them; or shall 1 say the innocent sensuous pleasures? e.g. we keep our eyes in our heads and take in impressions through them; whereas civilization bids us put them in our pockets, and is mostly obeyed. And it must be said that there is reason in this since civilization is such a foul slut, and wherever she can manage it gives us nothing pleasant to look at, so that we are driven to have to thank her, like my friend Shaw, for the wreaths of steam which float from the funnel of a locomotive; at all events when they are not defiled by the smoke of the coal which the Company has no business to burn but which it generally does. However from such impressions, we take our pleasure as well as our pain; but there is so much pain in them that on the whole they do but add to our discontent; for as things go whatever we see almost has some share of that sickness in it, and we long and long to better these things: we cannot look upon the world merely as if it were an impressionist picture, or be pleasantly satisfied with some ruinous piece of picturesque which is but the envelope for dullness and famine. ${ }^{2}$ But there again comes in our hope: for if we live in the present on such crumbs as we can pick up amidst the general waste and ruin, we live generously enough in the future; and one part of our pleasure in the ordinary life of today, the animal life I mean, and the goings on in field and flood and sky and the rest of it, comes from the fact that we see in them the elements of which the life of the future will be built up far more than of the thought of to day, its literature, its so-called art, its so-called science.

In sum our hope is so generous that we believe that whatever there

\footnotetext{
1 Morris constantly uses this word as generally descriptive of the 19th century bourgeois society, and seems to have been influenced in doing so by Fourier. 2 In his mature years, Morris is decidedly anti-Romantic, and his hatred of the picturesque is expressed in similar terms in News from nowhere: "our villages are something like the best of such places [...] Only note that there are no tokens of poverty about them: no tumble-down picturesque" (Stories in Prose etc., p. 68).
} 
is which is distinctive of the sickness of civilization will dissappeara before our regained freedom: what we aim at, the purpose for which we want to use the instrument of the transition, which is what some understand by the word Socialism ${ }^{1}$ is no mere rectification of our present society, but the construction of a new society in which we shall adore what we used to burn, and burn what we used to adore.

How shall we live then? Whatever system of production and exchange we may come to, however justly we may arrange the relations of men to one another we shall not be happy unless we live like good animals, unless we enjoy the exercise of the ordinary functions of life: eating sleeping loving walking running swimming riding sailing we must be free to enjoy all these exercises of the body without any sense of shame ${ }^{2}$ without any suspicion that our mental powers are so remarkable and godlike that we are rather above such common things. Also I will say in the teeth of the very natural repulsion to bodily labour that our present conditions force upon us we must be strong and healthy enough to enjoy bodily labour, ${ }^{3}$ a good stout wrestle with the forces of nature which will make us feel our power. I do e.g. hope most sincerely that we shall manage not to [be] so driven for the production of food as not to allow ourselves the pleasure of getting in the harvest by hand, ${ }^{4}$ or, a great many of us, raising our own potherbs, of course a Morris's spelling

1 See Introduction. Cf.: "in short to some of us it seems as if this view of Socialism simply indicates the crystallization of what can only be a transitional condition of society, and cannot in itself be stable" ("The Policy of abstention", in: May Morris, ibid., II, p. 436); "These two views of the future of society are sometimes opposed to each other as Socialism and Communism, but to my mind the latter is simply the necessary development of the former, which implies a transition period" ("True and false society", in: On Art and Socialism, ed. by Holbrook Jackson (London, 1948), p. 315).

2 This reaction against Victorianism appears in many writings of Morris; see, for instance, "The Society of the Future", in: May Morris, ibid., II, pp. 457-462. ${ }^{3}$ Morris reacts more than once against the then current contempt of manual labour; e.g., "I should think very little of the manhood of a stout and healthy man who did not feel pleasure in doing rough work" ("How we live and how we might live", in: Stories in Prose etc., p. 582); "the stupidity of that day, which despised everybody who could use his hands" (News from nowhere, ibid., p. 19). ${ }^{4}$ If, as will be seen later on, Morris is by no means adverse to the use of machinery in the industrial production of the future, he is deliberately hostile when agriculture is concerned. Cf.: "there would be many occupations also, as the processes of agriculture, in which the voluntary exercise of energy would be thought so delightful, that people would not dream of handing over its pleasure to the jaws of a machine" ("The Aims of Art", in: Stories in Prose etc., p. 600); "we should soon drop machinery in agriculture I believe when we were free" ("The Society of the Future", in: May Morris, ibid., II, p. 462). 
with due knowledge and skill. (Also I should hope that we should not find it necessary to shorten our lives as we do now by spending a great part of them in the condition of parcels sent from one place to another. ${ }^{1}$ I hold that going from one place to another (on the surface of the earth) may be made by no means a waste of time if we dont do it as parcels, especially if one can be happy enough not to think on the road. Indeed even when I am sent on as a parcel I do my best to get my eyes out of the brown paper sometimes.) Now all this would mean that our views on the subject of education would have to change somewhat: the equipment for life on the new terms would not and could not be the same as on the old: it is true that the capacities for dealing properly with the bodily side of life would grow to be a kind of habit: still I suppose except among the South-sea islands and such like places men have to learn swimming, and except in the Pampas, riding. And I cannot easily conceive a lad knowing how to dig and plough and reap and sow without learning, although that learning would not be gained in the technical school method, but as apprentices learn when it is anybody's business to teach them. Besides I think most people would want to learn two or three of the elementary crafts whether they intended to practice them as a main occupation or not, smithying carpentering (not cabinet-making) and mason's or bricklayers work, I am thinking about, and that would need definite instruction, lasting some time. ${ }^{2}$ Various minor arts like cooking ${ }^{3}$ and sewing would be learned very easily by children when they [are] very young; and they again would mean little more than the gaining of an easily a[c]quired habit. The education set on foot we should have first a great body of out-door occupations, dealing with work necessary to be done, ${ }^{4}$ agreeable to healthy and strong persons, and capable of being done excellently, that is of developing real pleasure in the doing, some of them perhaps to be done by individual work but most by means of cooperative; and all the parts of them in which excellence was not possible to be much developed could be done with little effort, almost

${ }^{1}$ Morris more than once condemns the modern hobby of travel for its own sake. In his Utopia, escapism is a feeling which has thoroughly disappeared. Ellen, in News from nowhere, says to the Guest: "of course people are free to move about; but except for pleasure-parties, especially in harvest and hay-time, like this of ours, I don't think they do so much" (Stories in Prose etc., p. 178).

${ }^{2}$ Morris's ideas about education are expressed in similar terms in $\mathrm{ch}$. V of News from nowhere.

${ }^{3}$ Morris was himself an excellent cook (see Mackail, op. cit., I, 223) and he often alludes to his capacities in this field: see, e.g., News from nowhere, ibid., p. 57. 4 There is no place for games and sports in Morris's Utopia. Pleasure should be derived from useful exertion, and its most pleasant form is what he calls "easyhard work" in News from nowhere. 
as a habit: Add to these occupations a few of what for shortness I would call indoor work, and also (an important addition) what we call art, in which I would include, beside the plastic and decorative arts, imaginative and measured literature and the pursual of knowledge for its own sake, and these I think will give ${ }^{a}$ most of the occupations necessary for a happy community: and for the life of me I cannot see why we should bother ourselves with occupations which are unnecessary. Let me try if I cannot arrange these occupations in groups a little more systematically adding some few perhaps doubtful ones.

1st. The open air arts; (I had better call them arts at once, because to my mind all work which is done by a man in the course of the due exercise of his faculties and therefore pleasureably is an art.) ${ }^{1}$

Agriculture and its kindred arts; gardening, fishing, butchering, ship and boat-sailing. Driving carts, trains, omnibusses ${ }^{b}$ and the like (a cross division here with distribution). The habits of swimming, good walking and running, and riding would be mixed up with these, and also an habitual knowledge of the ways and manners of non-human beasts.

Now as we shall live then I declare that anybody who did not take a pleasureable interest in some part of these arts and was not capable of working in them, would have to be considered as a diseased person - something less than a man, a burden on the community, if there were many such persons it would tend to the creation of a class of slaves, people doing the rougher work of the world only.

2nd. The domestic arts: The arrangement of a house in all its details, marketing, cleaning, cooking baking and so on; sewing with its necessary concomitant of embroidery ${ }^{2}$ and so forth. Once more whoever was incapable of taking interest and a share in some parts of such work would have to be considered diseased; and the existence of many such diseased persons would tend to the enslavement of the weaker sex. ${ }^{3}$

3rd. The building arts: masons, bricklayers, smiths, carpenters and the like and also the planners of buildings, engineers, and so forth. Of these arts what we now call art, i.e. decoration, appeals to the intellect

\footnotetext{
a Here Morris has omitted to delete his former version and you will have

b Morris's spelling
}

\footnotetext{
1 This is perhaps one of the pithiest expressions of Morris's conception of art and work, which is a vital element of his ideology and recurs ever and again throughout his writings.

${ }^{2}$ Embroidery was an important activity of the Morris Firm.

${ }^{3}$ In no other of his writings is Morris so positive and practical in his advocacy of sex-equality. In News from nowhere (ch. IX), women seem, of their own accord, to have chosen house-keeping as the natural occupation of their sex.
} 
through the eyesight, would form a necessary and integral part; therefore possibilities of excellence would here run high, and consequently only those would take a part in them who had some faculty for creation, as I believe most free men have; but doubtless there would be some lacking this faculty or possessing but little of it, who would prefer the rougher arts above mentioned; but as they would be doing their share of the necessary work and with pleasure, they would not be injuring any one by disease. For the rest it is clear that these arts are cooperative in the highest degree, no one necessary person's work being really separable from the whole mass of it.

4th. The workshop arts, weaving, pottery, dyeing ,printing (textiles and book) etc. Into most of these also art would enter and much the same thing is to be said of these as of the last group. In cases where art could not be an integral part of the work if it turned out to be necessary work, it would have to be done by machines as nearly automatic as possible ; ${ }^{2}$ but I should consider it a matter of course that those who tended such machines would do other work at once more pleasurable and more responsible; and whatever drudgery of this sort we could do without we should drop at once.

5 th. The disagreeable arts. I will assume though I am not sure that it is so, that there would be such indispensable arts, and then proceed to divide them into:

a - The rough disagreeable arts.

$\mathrm{b}-$ The smooth disagreeable arts.

By the first I mean such occupations as mining, skindressing, scavengering and so on. By the second I mean - well quill-driving of the less amusing kind, clerks work, official sauntering and so on. Of both these groups I say the same thing; as above, machines where possible, and the workers to have other occupation: but also strict enquiry as to whether they are necessary, and if not, abolition.

6 th. The arts concerning the distribution of goods; shipping of goods shopkeeping and market-managing of all kinds. I daresay it will be possible to find people to like such work and let them do their best at it; but I am sure that they will find digging and reaping, or even perhaps leather-dressing restful to them: and such rest they ought to have.

7th. The fine or intellectual arts: i.e. picture painting, sculpture, and the lesser or reproductive fine arts, such as engraving. Also imaginative literature, and the study of history and nature. Some of these in which a good deal of actual manual labour is necessary might be fol-

1 Morris professes that architecture is the mother of all other arts, and this is an important theme in his Utopia.

2 See Introduction. 
lowed exclusively; the others certainly not; and even in the first, or manual fine arts, rougher manual work would be desirable, unless in cases, if there be any such, (which again I doubt) where extreme finesse of hand is so necessary that it would not do to roughen the hand by harder labour. In any case $\mathbf{l}$ feel sure that it would not do for men to be absorbed entirely in such arts. It would tend to disease, to anti-social habits, which would burden the community with a new set of idlers, and (if the others were such fools) in the long run to a new set of masters. ${ }^{1}$

Before I go further I ought to say that though I don't doubt that a due amount of organization and direction would be required in the diverse branches of occupation I am very far from thinking that it would be either necessary or desirable to prescribe to people what occupation they should follow; I am assuming only that opportunity will be afforded for people to do what they can do well, and that the work as far as the relations of men go will be voluntary; nature will be the compeller, in a sense the only enemy: yet an enemy that asks to be vanquished.

Now having given you my ideal as to the occupations of men in a free community, I have but to add my views as to the possibility of its being realized sometime or other: [it] is what might be called the political side of the question.

Decentralization and equality of condition are the necessary concomitants of my ideal of occupation: but I am not clear as to whether they should be looked on as the cause or the effect of the state of things foreshadowed by that ideal. But I think, that granted the second, the first will tend to come naturally. Difficult or if you please impossible, as it may be to conceive of such a change as will come of the abolition of the great central power of modern times the world-market as we know it with all the ingenious and intricate system which profit hunting commerce has built up about it, because of it and by means of it, yet after all it must develope into something else, and that something else can hardly be a perfecting of its perfection, but rather its contradiction, which is the conscious mutual exchange of services between equals. Nay if things now going on can be fairly understood

${ }^{1}$ Diversified occupation is a constant theme with Morris: this will be the main element of the transformation of labour into pleasure in his Utopian world. An interesting idea expressed here is the fear of specialised intellectual workers tending to form "a new set of masters". This idea, which shows Morris's violent opposition to Carlyle's notion of an "aristocracy of talent", appears in various articles published in Commonweal ("The Reward of Genius", Sept. 25th, 1886, p. 205; "Artist and Artisan", Sept. 10th, 1887, p. 291). 
by us who live amongst them are there not signs of the coming change already visible to us? The Republic one and indivisible of 100 years ago is passing through a phase of bourgeois corruption and the only hope of France is that it will come out at the other end a Federation of Free Communes. ${ }^{1}$ The Unity of Germany has been accomplished but a few years; yet here are we waiting for but one event, quite certain to happen sooner or later, the defeat of the German Army, to break it up again into a federation with socialism as its aim. And at home the principle of Federation is conceded in the matter of Ireland by all but the stupidest of the reactionaries $;^{2}$ while the Tories themselves, driven on I believe by a blind fate, have given us in the County Councils the germs of revolutionary local opposition to centralised reaction. ${ }^{3}$ Thus then before centralization is quite complete even, the change in the direction of its opposite seems to have begun, and once begun will surely go on till the necessary practical decentralization has been arrived at. That decentralization seems to me looking out from our present condition to be necessary in order to give all men a share in the responsibility of the administration of things which I hope will take the place of the government of persons: ${ }^{4}$ you will understand that I admit the possible necessity of a certain amount of mechanical centralization, such as a central administration of railways in such and such a geographical district, which after all would not be centralization but the direct outcome of Federation. ${ }^{5}$

1 The Paris Commune of 1871 is a lasting inspiration of Morris's Utopian ideal of decentralisation in a Communist society. Cf. Socialism, its growth and outcome, p. 199.

${ }^{2}$ This statement is of great interest, as it shows Morris's evolution in his approach to the Irish question since the "purist" years 1885-86 (see the articles he then published in Commonweal), when he professed that the campaign for Home Rule was meant to divert the Irish people from genuine revolutionary action.

${ }^{3}$ County Councils had been set up in 1888. On January 21st, 1889, Morris was writing to his elder daughter Jenny: "On the whole the London election has been a great blow to the reactionists; though I don't suppose that the County Council can do much directly as they are now constituted: yet they may become Socialist in feeling, and so make a rallying-point for a kind of revolt against the Parliament." (The Letters, pp. 307-8)

"Saint-Simon was the inventor of this famous phrase, which was resumed by Fr. Engels in his theory of the "withering away of the State". W. Morris does not seem to have been well acquainted with the works of Saint-Simon. On the other hand, he was strongly impressed by Engels's Socialism: Utopian and Scientific (an excerpt from Anti-Dühring) which he seems to have read as early as 1885 in the French edition published by Paul Lafargue in 1880.

"The idea of a "Federation of independent communities" appears for the first time in a lecture of 1885, "The Dawn of a new Epoch" (in: Signs of Change), and will find full expression in 1893, in Socialism, its growth and outcome, ch. 
I also admit that the form which the decentralization or Federation will take is bound to be a matter of experiment and growth: what the unit of administration is to be, what the groups of Federation are to be; whether or no there will be any cross Federation as e.g. Craft-gilds and Cooperative Societies going side by side with the geographical division of wards, communes, and the like - all this is a matter for speculation, and I don't pretend to prophecy a about it. ${ }^{1}$

I may say however in parenthesis that my temperament leads me to believe that we shall be able to get rid of one outward and visible sign of commercial and official centralization; our great cities, and closely packed manufacturing districts.

As for the first, the great centres like London, Paris and Berlin, they are surely the outcome of the desperate struggle for life which competition under monopoly engenders on both sides the monopolizers and their slaves. They are counting houses of commerce; the jobbing houses of officialism; the lairs for the beasts of prey big and little that prey upon the follies and necessities of a huge mass of people who have no time to find out what they want; and must have all their wares from the bread they eat down to a new novel or a play at the theatre forced upon them like a sharper forces a card: they are the sweating dens to which starvation drives up the starvelings of the rest of the country, so that they may eat a morsel of bread while they cast the dice desperately for that twenty millionth part of a chance to escape from the proletariat which is the yard of earth between modern society and the volcano it stands upon. I do not deny lastly that they are the camps to which the soldiers of revolution must flock if they are impelled to do anything to further their hope before they die. But granted the change of conditions which we all hope for, of what use will be these monstrous aggregations of confusion? No camp will be needed, for militant socialism will be over: no man will hurry up to be sweated, for his decent livelihood will be assured to him. ${ }^{2}$ People will have leisure to

\section{a Morris's spelling}

$\mathrm{XXI}$. The present lecture is the only instance in which the principle of federation is applied to the railway system.

1 The dual system of federation, geographical and professional, is alluded to for the first time in a lecture of 1888, "What Socialists Want" (in: The Unpublished Lectures of William Morris, p. 231), and will be fully developed in Socialism, its growth and outcome, ibid.

${ }_{2}^{2}$ This Marxist view of the historical role of large agglomerations is nowhere, in Morris's works, so explicitly developed as here. One year before, in 1888, in his lecture "The Society of the Future", he had already written: "Again, the aggregation of the population having served its purpose of giving people opportunities 
think what they want and resources to have the reality of it; so that the parasites above mentioned will not exist, for there will be no carrion for them to feed on. Official jobbery will be dead; and profit-hunting will need no counting house or will have to seek it of the Father of Lies ${ }^{1}$ to whom it will have returned. There will be no use for this monstrous muck heap in which we swelter to-day. But in case anyone should be inclined to regret what $I$ have heard called the stir and movement of a big city, I will just say two things: first, that in those post-monopoly days, when at the very least there will be more of an approach to equality, there will relatively to men be more intelligent and thoughtful men: we do everything wastefully now; so if you want a dozen highly cultivated and thoughtful persons you must have 12000 proletarians at their back in order to produce the due element of stir and movement for those 12 treasures: as a practical man I cannot approve of the plan. Again you must remember that the dulness and monotony of countrylife at present, of which many complain (but not I) is the wrong side of the hubbub of town life; since the town sucks the blood of the country in all things: in postmonopolist days I hope, as I have already said that we should reform this. ${ }^{2}$

As for the great factory districts, it seems to me that they also would dissappeara : granted that it is possible to produce goods cheaper when you have labour and material gathered together in the closest space possible; I am sure that in post monopolist days when the "sword of cheapness" is no longer necessary as an offensive weapon against other nations, we should come to the conclusion that we might buy cheapness too dear, that hell was altogether too high a price for it, and that it would be worth while to work a little longer in order to live in a pleasant place. Of course we must all admit that these last centres are centres of profit-bearing manufacture and huckstering, but of nothing else - save dirt. But now I must say that this decentralization with all the decent life and manly responsibility that will come of it can only be

\section{a Morris's spelling}

of inter-communication and of making the workers feel their solidarity, will also come to an end" (May Morris, op. cit., II, p. 461). The disappearance of large towns is a constant theme of Morris's Utopia, though, in News from nowhere, he does not abolish London, but, as it were, countrifies it. He seems to have been strongly influenced in his hatred of large towns by Cobbett, whose Rural Rides he greatly admired. - In Socialism, its growth and outcome, he will again use the phrases "Socialism militant" and "Socialism triumphant", which will be the titles of its two final chapters.

${ }^{1}$ I.e. the Devil (John, VIII, 44).

2 Morris's Utopia is the constant illustration of the idea contained in the Communist Manifesto of the solution of the contradiction between town and country. 
got in any measure at all as a forecast of advancing equality, and can only be reached fully when we have attained to practical equality; that equality is in fact our ideal.

Indeed I can only explain the fact that some socialists do not put this before them steadily by supposing that their eager pursuit of the means have somewhat blinded them to the end.

Surely there are but two theories of society; slavery on the one side; equality on the other. The first theory supposes that use must be made of the natural diversity of capacities in men to cultivate a class of superior beings, who are to live on the lack, the unhappiness in short, of the inferior class. The second theory says, when you have got hold of the strongest and cultivated him into a stronger, you can by no means be sure that you have got hold of the best; he is only the strongest under certain artificial conditions which you yourselves have made; and you can never tell how many far better than he you have oppressed into nothingness by your masterful folly: satisfy a man's needs, and what there is in him will come out of him for your benefit and his, and you can't get out of him more than he can do. That is what communism says, ${ }^{2}$ and the only way I can see to traverse it is to say, I intend to have that man for my property, and all that he does is mine, whether it is little or much, only if he doesn't make more than enough to keep himself, he will be of no use to $\mathrm{me}^{3}$ and I will kill him as I would an old worn out horse. Any stage between these two theories I can only understand on the grounds that the antislavery man is bribing the slave owner to keep him quiet until he becomes too weak to resist having his slave taken from him and made free. As a transitional step I say nothing about this proceeding, ${ }^{4}$ as an ideal I cannot fail to see that it is incomplete and illogical. No other ideal on this matter of livelihood in a post-monopolist community appears to me

1 In fact, the problem of necessary industrial concentration will never be solved satisfactorily by Morris. The only concrete approach to a solution will be found in Socialism, its growth and outcome, when he writes: "there would be two ways, either of which might be chosen. First, to have volunteers working temporarily in a strictly limited and comparatively small 'black country', which would have the advantage of leaving the rest of the country absolutely free from the disorder and dirt. And secondly, to spread the manufacture in small sections over a territory so large that in each place the disadvantages would be little felt!" (pp. 312-3).

$2 \mathrm{Cf}$. Marx, in his description of Communism in the Critique of the Gotha Programme: "From each according to his capacities, to each according to his needs." ${ }^{3}$ The Marxist theory of value and surplus-value appears under many forms in Morris's writings.

${ }^{4}$ Morris is speaking to a Fabian audience and is cautious in his phrasing. He generally uses a more uncompromising and harsh language in his rejection of reformism. 
worth considering that the satisfaction of each man's needs in return for the exercise of his faculties for the benefit of each and all: to me this seems the only rational society. And this means practical equality. For when you have satisfied the man's needs what else can you do for him?

You will say doubtless what are his needs? Well of course in such an audience I need not deal with the usual quibbles of people who think that we socialists have never thought of any of the difficulties which arise in anyones mind when such questions are started. But those of you, if there [are] any here, who think that one useful person should have (compulsorily) a different scale of livelihood than another useful person I want to put a point or two to you that have occurred to me (and very likely to you also). 1st - Given a poor community which could satisfy the average elementary needs of each man for food and shelter, but could do nothing else; would you think it right (or ideal let us say) for the so called more useful man to have anything extra for his excellence? If he did so, wouldn't he starve the others, since they would then have so much less of necessaries as he had so much more? wouldn't they be his slaves then, whatever the nature of the compulsion was which he used? for they clearly wouldn't do it without compulsion. Well carry it further and suppose the community wealthier, even quite wealthy. There is still surely a due standard of livelihood, of leisure and pleasure which can be upheld for the citizens in general, why should they be deprived, against their will of what they can have and what they desire, of what they can have if they are not compelled to give it up. Either they have more than they need, in which case they had better not produce so much, ${ }^{1}$ or they have only as much as they need, and in that case if they are compelled to give up some of that, they are not free men. Again I seem to see another drawback to this new class of ability: I assume that all men's needs will be satisfied according to the measure of the general wealth: well the superior man will have his needs satisfied; and once again what more can you do for him than satisfy his genuine needs. It seems to me that even at the best what he would do with his extra pay would be to surround himself with extra luxuries, and that the result of that again would be the creation of a new parasitical and servile class which could not fail to be an injury to the Community. In short I can think of no special reward that you can give to a man of special gifts but license to do harm to his fellow-citizens, which is a strange reward for having been of special service to them. Lastly remember that when a man has

1 Cf. "we make no more than we want" (News from nowhere, ibid., p. 90). 
special gifts the exercise of those special gifts are a pleasure to him which he will not forego if he can help it; therefore while on the one hand it is unjust and unsocial to compel the citizens to give up their ordinary advantages for the nourishment of this Queen Bee, so on the other hand nature does not compel them. Whatever is in him he will give freely if you leave him free and provide him with due opportunity for the exercise of his faculties. That is if you let him have due unprecarious livelihood with leisure and pleasure according to his desires, and the free use of raw material and the instruments of labour. ${ }^{1}$

Other things I can see of the way in which we should live then, which you can also see I suppose: the splendour of public and the quiet dignity of private life, ${ }^{2}$ and in general all the real pleasures which would come of our being wealthy and no longer rich $;^{3}$ of all which pleasures the greatest now seems to be a negative one, the relief of no longer living in one or the other of two opposed camps of enemies, which we feel certain must one day fall upon each other ruining many a hope and many a quiet life in the process; while in the meantime ethics are in hopeless confusion and pessimism increases in days when we find it hard to understand what vices and virtues mean since the collective crime of class wrong is so overshadowing and overwhelming. Of course I do not pretend to have given anything like an inclusive account in detail of what our ideal of the new world is; 4 since I feel I have been somewhat disjointed in what I have said, I will very briefly run over the points concerning which I may differ with some here.

First the change, from Monopoly to Freedom, when it is complete, will make a new world for us, and will be far greater than any change that has yet taken place in the world.

a Sic

1 This argument had been developed at length in the two Commonweal articles of 1886 and 1887, "The Reward of Genius" and "Artist and Artisan." to which I have previously referred.

${ }^{2}$ Cf.: "Surely when true society takes the place of false, we shall raise beautiful and magnificent halls with their surroundings for the use of all. But the contrast will not then be between splendour and sordidness, but between splendour and special beauty and the due simplicity of the dwelling of a private person which is quite consistent with beauty and convenience." "Notes on News", in: Commonweal, May 28th, 1887, p. 172).

3 This distinction between wealth, i.e. plenty, and riches, i.e. money and power, which had been suggested by Ruskin in Unto this last, is always very clear and precise in Morris's writings. Its first expression appears in a lecture delivered in 1883, "Art, Wealth and Riches" (in: On Art and Socialism).

4 The feeling of being unable to cope with every aspect of life in a communist society will be implicit in the sub-title of News from nowhere: "Being some chapters from a Utopian romance". 
2nd. - We may have in appearance to give up a great deal of what we have been used to call material progress, in order that we may be freer happier and more completely equal.

3rd. - This would be compensated (a) by our taking pleasurable interest in all the details of life, and (b) by our regaining the pleasure of the eyesight, much of which we have already lost, and more of which we are losing everyday.

4th. - Instead of toiling for some blind force, a mixture of necessity and nightmare, we should be conscious of doing useful work for our neighbours who were doing the like for us. As a result there would be no waste of labour, as useless occupations would be got rid of speedily.

5th. - Work thus obviously useful, and also adapted to the capacity of the worker would mostly be a pleasant exercise of the faculties; necessary work that would otherwise be drudgery would be done by machinery or in short spells: no one being condemned to work at unpleasant work all his life.

6th. - As no incentive to work would be needed save its obvious necessity and the pleasure involved in it; $\mathbf{1}$ and as the division of labour into more or less worthy work deserving different standards of livelihood would create fresh classes, enslave the ordinary man, and give rise to parasitical groups, there would be no differentiation of the "reward of labour". (This last phrase I consider a misleading one, involving a begging of the question). I am aware that this implies the abolition of private property.

7th. - Nationalities as rival corporations would have ceased to exist and centralization in our present sense of the word would give place to Federation for definite purposes of small units of administration, so that the greatest possible number of persons might be interested in public affairs.

Some such ideal as this I believe will be realized, and I earnestly hope it will be. We have been told that the logical sequence of the developement ${ }^{a}$ of man's ingenuity will involve the gradual loss of his bodily faculties, and this seems probable: but the logical sequence of events is sometimes interrupted and turned aside by the historical; and my hope is, that now we know, or have been told that we have been evolved from unintelligent germs (or whatever the word is) we shall consciously resist the reversal of the process, which to some seems

\section{a Morris's spelling}

1 Cf.: "it cannot be too often repeated that the true incentive to useful and happy labour is and must be pleasure in the work itself" ("Looking Backward", in: Commonweal, June 22nd, 1889, p. 194). 
inevitable, and do our best to remain men, even if in the struggle we become barbarians; which latter fate I must confess would not seem to me a very dreadful one. ${ }^{1}$

William Morris

1 Morris's hatred of "civilisation" made him hesitate for some time between two Utopian ideals : a return to barbarism and Socialism. The reading of Jefferies' Utopian novel, After London, which described England reduced to primitive conditions of life by a natural catastrophe, had filled him with enthusiasm in 1885. Yet, as early as 1884 , he had found a dialectical solution of the contradiction when, in his lecture "Art and Socialism", he had hailed "the change in store for us hidden in the breast of the Barbarism of civilisation - the Proletariat" (Stories in Prose etc., p. 636). In later years, he became increasingly interested in the study of primitive societies, and published in Commonweal (July 19th, and August 16th, 1890) a long article, entitled "The Development of modern society", part of which is a faithful summary of the theses set forth by Engels in his Origin of the Family. The same inspiration was already obvious in some of his late prose romances, in particular The House of the Wolfings (1888). The tendency to integrate the early Teutonic direct democracy in his Utopia is clearly perceptible in News from nowhere, and the use of the old English word "Mote" for the assembly of the people is quite significant. 